\title{
Branch Union Morphology Affects Decay Following Pruning
}

\author{
Edward F. Gilman and Jason C. Grabosky
}

\begin{abstract}
Branch diameter relative to the trunk diameter (aspect ratio) affected the extent of discolored and decayed wood in the trunk of seedling-propagated red maple (Acer rubrum L.) after branch removal. More discoloration resulted from removing codominant stems than removing branches that were small compared to the trunk. Removing limbs that originated from lateral buds resulted in the same amount of discoloration and decay as removing suppressed limbs that were once the leader. This result provides indirect evidence that a small codominant stem suppressed by pruning techniques designed to slow its growth rate can result in a branch protection zone at the union. There was no relation between the presence of a bark inclusion and decay 4 years after making pruning cuts.
\end{abstract}

Key Words. Acer rubrum; aspect ratio; bark inclusions; branch protection zone; codominant stems; compartmentalization; decayed wood; discolored wood; pruning; wounding.

The importance of the branch protection zone (BPZ) in limiting trunk infection after branch injury or removal has been demonstrated (von Aufsess 1975, 1984; Shigo 1985). The BPZ is generally recognized as a three-dimensional coneshaped volume of morphologically and physiologically unique wood at the base of a branch. The xylem within the BPZ can become occluded with decay-resistant compounds (von Aufsess 1975; Green et al. 1981) and is structurally distinct from normal xylem with thicker cell walls, higher specific gravity, fewer fibers, more parenchyma, and shorter and fewer vessels (von Aufsess 1975; Ewers and Zimmermann 1984). In several species of maple trees, the BPZ is delineated by a green boundary, approximately 0.5 to $2 \mathrm{~mm}$ ( 0.02 to 0.08 in) wide, visible in a medial longitudinal section of the branch union.

The BPZ separates decayed and discolored wood in the branch stub from healthy sapwood in the trunk (Green et al. 1981; Pearce and Woodward 1986; Pearce 2000). Branch diameter relative to the trunk diameter (aspect ratio) affects the amount of discolored wood that develops in the trunk 4 months after branch removal in seedling-propagated red maple (Acer rubrum L.) and live oak (Quercus virginiana Mill.) (Eisner et al. 2002a). More discoloration has been observed after removal of codominant stems on young trees than after removal of branches that were small compared to the trunk diameter.

Branch union anatomy was studied extensively for its role in the movement of water within trees (Zimmermann 1978, 1983; Ewers and Zimmermann 1984). A zone of constricted xylem vessels was found at the base of each branch. This vessel anatomy restricts the flow of water into the branch. The spatial position of this constricted tissue corresponds to the location of the BPZ. Movement of water through this zone was directly proportional to the ratio of branch diameter to stem diameter (Eisner et al. 2002b). Junctions with perpendicular branches had lower hydraulic conductivities than more upright branches. The presence of visible branch collars was also a good indicator of low branch junction conductivity.

Eisner et al. (2002a) showed that xylem water flow and advancement of discoloration through the branch union were a function of aspect ratio at 4 months after pruning red maple. We wanted to know whether the amount of discolored and decayed wood that formed 2 and 4 years after pruning was related to branch union morphological characteristics such as aspect ratio, branch size, origin of the limb, presence of bark inclusions, and wound closure rate.

\section{MATERIALS AND METHODS}

Twenty field-grown seedling-propagated red maple (Acer rubrum L.) trees of similar provenance were selected for study in USDA Hardiness Zone 8b in Gainesville, Florida, U.S. The red maples were planted in 1995 from \#15 containers. In 1999, when this study was initiated, the trunk diameters varied from 10 to $15 \mathrm{~cm}$ (4 to 6 in) at $15 \mathrm{~cm}$ (6 in) above the ground and tree heights ranged from 4 to $7 \mathrm{~m}$ (13.2 to 23.1 ft.). Trees were growing on a well-drained Millhopper Sand (loamy, siliceous, hyperthermic Grossarenic Paleudults) soil and were irrigated periodically during the study period.

On each of these 20 trees, branch unions were selected based on branch diameter [10 to $25 \mathrm{~mm}$ (0.4 to $1 \mathrm{in})$ ] and aspect ratio. Two branches on each tree were chosen in each of six aspect ratio categories for a total of 12 branches per tree (Eisner et al. 2002a). For each branch union, trunk and branch diameter were measured $15 \mathrm{~mm}$ (0.6 in) above the branch bark ridge, and the aspect ratio (ratio of branch to trunk diameter) was calculated. The presence or absence of a branch collar was also recorded at this time. A branch collar 
was defined as a distinct swelling on the branch base where branch wood joined trunk wood.

In September 1999, the 12 branches were removed from all 20 trees. The pruning cuts extended from just outside the branch bark ridge on the upper side of the branch to the outside of the branch collar on the lower side. In cases where branch collars were not readily apparent, the cut was made from just outside the branch bark ridge perpendicularly through the branch. In earlier studies, this technique resulted in little cambial dieback on the trunk beneath the cut (Eisner et al. 2002a).

The branch unions from 10 trees ( 12 unions per tree $\times 10$ trees $=120$ branch unions) were harvested in January 2000 ( 4 months after pruning), from 5 trees (60 branch unions) in January 2002 ( 2 years after pruning), and from 5 trees in January 2004 (4 years after pruning) for a total of 240 branch unions. The harvested samples included the branch union with approximately $2.5 \mathrm{~cm}(1 \mathrm{in})$ and $10 \mathrm{~cm}(4 \mathrm{in})$ of intact trunk above and below the branch, respectively. All samples were then split with a sharpened metal wedge along the medial longitudinal plane (i.e., through the pith) and shaved with a razor blade to expose the branch and trunk piths. The amount of discolored (darker than normal) and decayed (darker and softer than normal) wood that formed after branch removal was scanned, measured, and normalized according to Eisner et al. (2002a). Data were normalized against sample trunk cross-sectional area to account for scaling influences between cut locations and then $\log 10$ transformed for data analysis (Eisner et al. 2002a).

At the time of dissection, the presence or absence and length of included bark visible on the medial longitudinal surface was recorded. Pruning wound closure after unions were split was categorized into the following categories: totally unclosed (woundwood about at the edge of the pruning cut), mostly unclosed (woundwood beginning to grow over the pruning cut), half closed (about half of the pruning cut covered with woundwood), mostly closed (woundwood mostly covering the pruning cut), and completely closed (woundwood completely covering the pruning cut). Lastly, samples were evaluated for the presence or absence of pith connection. Pith was classified as connected if branch and trunk pith were continuous.

The stepwise and GLM (SAS Institute Inc., version 8.0) procedures were used to test the impact of all continuous variables (aspect ratio, branch diameter, bark inclusion length, wound closure, time) on the length and area of discoloration and decay that developed after branch removal. The $t$-test was used to compare equality of slopes of linear lines relating decay and discoloration with time. The Tukey studentized range (HSD) contrast of means procedure was used to analyze the impact of class variables (presence of visible branch collars, pith connections) on discolored and decayed area. The frequency procedure was used with chi- square analysis and the Fisher exact test to evaluate relationships among class variables. In all statistical analyses, $P$ values less than 0.05 were considered significant unless otherwise specified.

\section{RESULTS AND DISCUSSION}

The model that best described the amount of discoloration was Log10-normalized discolored area 4 years after pruning $=-0.079+0.408$ (aspect ratio) +0.106 (aspect ratio*trunk diameter); $R^{2}=75 \%$. This model indicates that the amount of discolored wood that formed after a pruning cut was dependent on the diameter of the cut and the ratio of the branch to the trunk diameter (aspect ratio). The area of discolored wood behind the pruning cut increased significantly $(P<$ 0.01 ) as the aspect ratio increased from 0.25 to 1.0 at 4 months, 2 years, and 4 years after branch removal (Figure 1). An aspect ratio of 1.0 indicated that the removed stem was the same diameter as the trunk. Little discoloration occurred when aspect ratio was less than 0.2 . The $t$-test showed that the slope of this relationship was greater at 2 and 4 years than at 4 months after pruning; the slope 2 years after pruning was similar to the slope 4 years after pruning. This increase in slope indicated that trunk discoloration increased over time at a greater rate when removed branches were large in relation to the trunk compared to those that were small in relation to the trunk. Discoloration progressed very slowly in the 4 years after removal of small branches on larger trunks.

There was no relation between the depth of discoloration into the trunk and the aspect ratio or branch diameter, but the depth (length) of discoloration increased with time (Figure 2). Since the depth of penetration was not related to the aspect ratio, the increasing discolored area with aspect ratio described in the above model suggests a filling in of the discolored area. In other words, the discoloration produced advancing thin streaks at small aspect ratios, and discoloration filled in between the streaks as the ratio increased. These results are consistent with observations of large columns of decay after removal or breakage of codominant stems on trees that compartmentalize poorly, especially when the stems are large in diameter (Shigo 1985, 1986). Our results also support the relative absence of such decay in hardwood tree species with branches that remain small compared to the trunk (Toole 1961). Something other than aspect ratio appears to determine the penetration of decay.

The area of discoloration 4 months after pruning was significantly greater for branches with pith connections than for those without (Eisner et al. 2002a), but not 2 and 4 years after pruning (data not shown). Apparently the lack of pith connection between the removed branch and the remaining stem played a role in retarding movement of advancing fungi soon after pruning, but its importance diminished with time. These results corroborate past observations that pith connections are associated with poor compartmentalization at the branch 


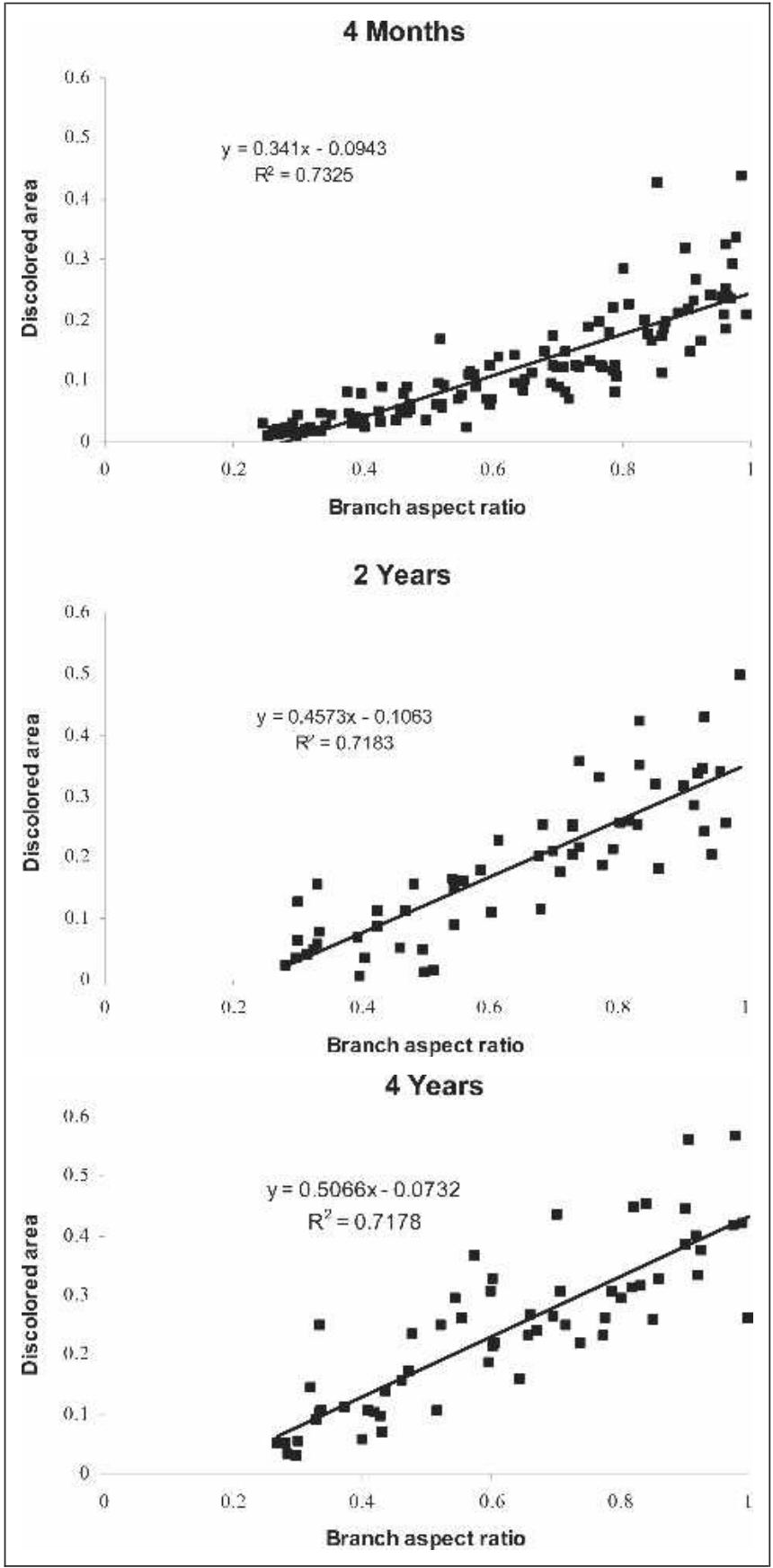

Figure 1. Log10-normalized discolored area $\left(\mathrm{cm}^{2}\right) 4$ months, 2 years, and 4 years after removing branches of different aspect ratios from red maple. The aspect ratio is the diameter of the removed branch/trunk diameter directly above the branch. The slope of the lines at each harvest shows an increasing rate of decay over time in the larger branch aspect ratios.

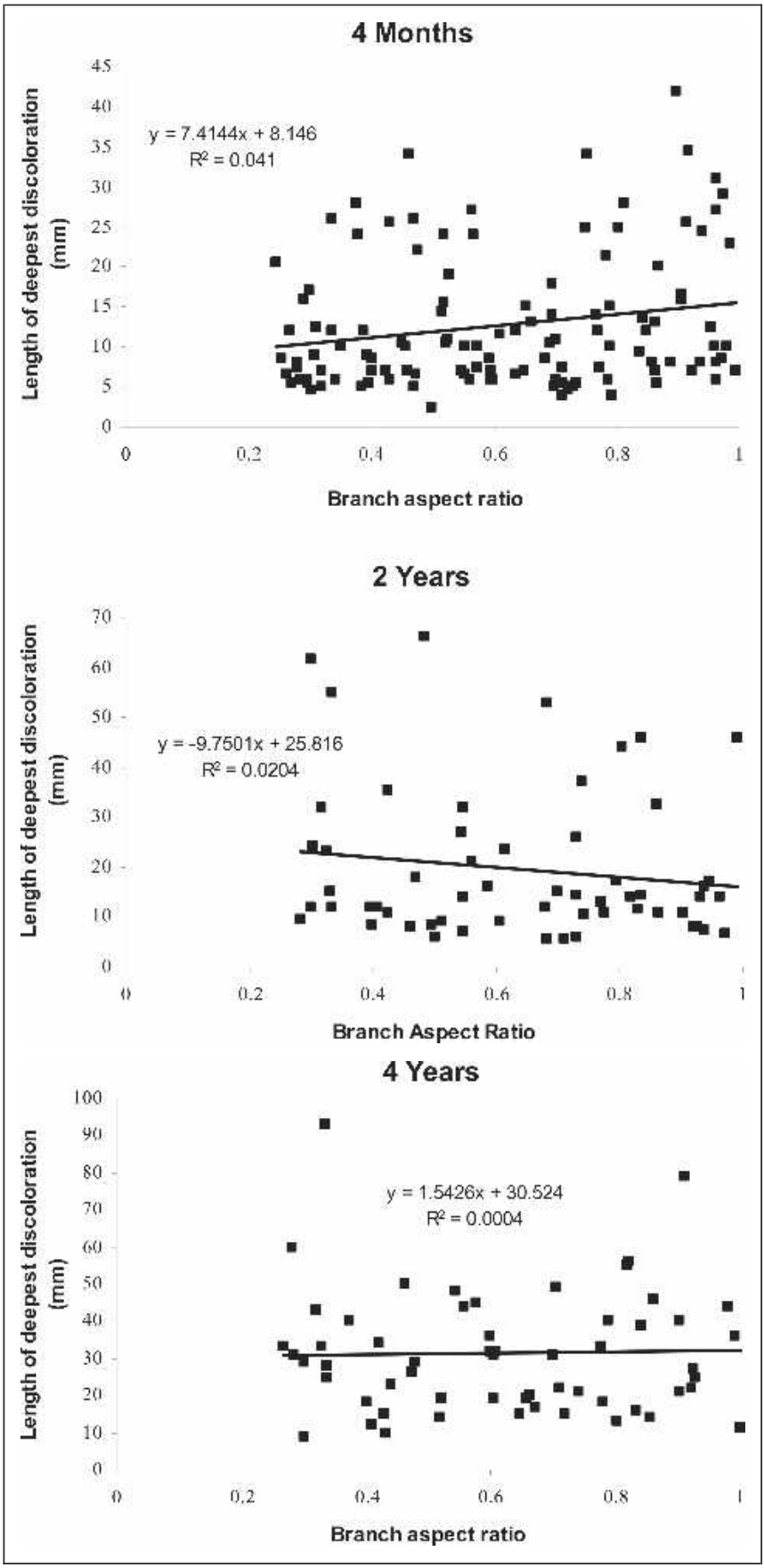

Figure 2. Length of penetration of discoloration in the trunk 4 months, 2 years, and 4 years after branch removal. 
junction (Shigo 1986) at least initially, but not for observations 2 and 4 years after the pruning cut.

In red maple trees grown from seed, a branch that originates from a lateral bud commonly assumes the role of the leader by growing larger than the original leader. Four years after pruning, the relationship between the $\log 10$-normalized area of discoloration and decay and the aspect ratio was not dependent on the origin of the removed limb (Figure 3). Removed limbs that originated from a lateral bud resulted in the same amount of discoloration as suppressed limbs that were once the leader.

This research provides indirect evidence that a codominant stem or a branch that is large relative to the trunk diameter that is suppressed by pruning techniques designed to slow its growth rate can result in a BPZ, at least on relatively small branches. This result is desirable because the BPZ retards advancement of decay into the trunk (Eisner et al. 2002a). More research is needed to confirm the suggestion that limbs subordinated with pruning can develop a BPZ just as in branches that naturally remain small in comparison to the

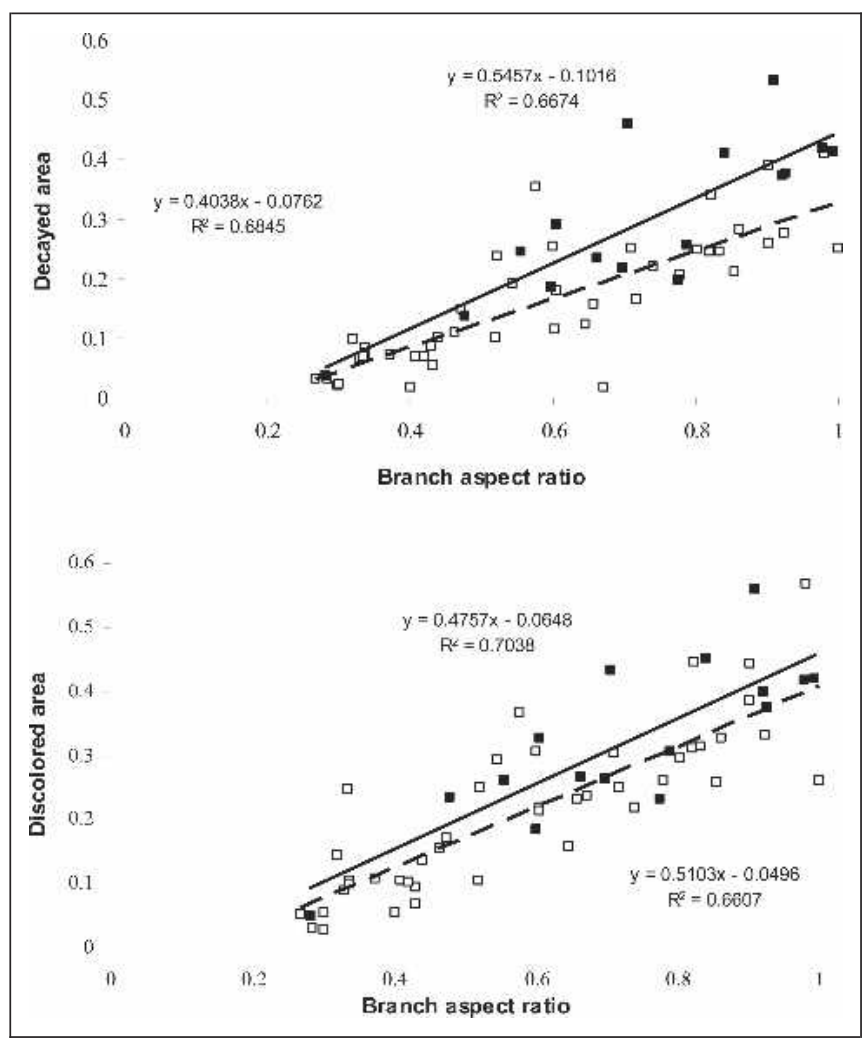

Figure 3. Log10-normalized decayed and discolored area $\left(\mathrm{cm}^{2}\right) 4$ years after removing branches of different aspect ratios from red maple. Solid line with filled squares indicates that the origin of removed branch was the main stem; dashed line with hollow squares indicates that the origin of removed branch was a lateral branch. trunk. A BPZ is unlikely to develop when very large limbs are suppressed by pruning.

There was no relationship between the presence of a bark inclusion in the union of the removed branch and decay 4 years after making pruning cuts (data not shown). This suggests that a BPZ can form even in the presence of a bark inclusion. We also found that some unions with inclusions had visible collars, and collars have been associated with a BPZ (Eisner at al. 2002a).

Bark inclusion length was greater $(P<0.06)$ when the removed branch originated as a trunk [inclusion length $=11$ $\mathrm{mm}(0.44 \mathrm{in})]$ than when the removed branch originated as a lateral bud [inclusion length $=3 \mathrm{~mm}(0.12 \mathrm{in})$ ]. Some unions stopped developing a bark inclusion and began forming connective tissue after pruning. The diameter of the opening over the pruning wound was nine times greater [3.7 $\mathrm{mm}(0.15 \mathrm{in})]$ on unions without an inclusion than on unions with an inclusion [0.4 mm (0.016 in)]. Only 1 in 15 pruning cuts with inclusions was still open 4 years after pruning (Figure 4). This indicates that closure occurred more quickly when we removed a branch with an inclusion than one without an inclusion. Wound closure was not correlated with any other measured parameters. Neely (1988) found that flush cuts closed faster than pruning cuts made at the edge of the collar. Despite quicker closure, decay behind flush cuts was greater than behind pruning cuts executed at the edge of the collar (Biggs 1989). Perhaps the presence of a BPZ allows the tree to allocate resources to processes other than closing appropriately executed pruning wounds on branches without inclusions.

The amount of discolored and decayed wood resulting from pruning appears to be minimized by removing only

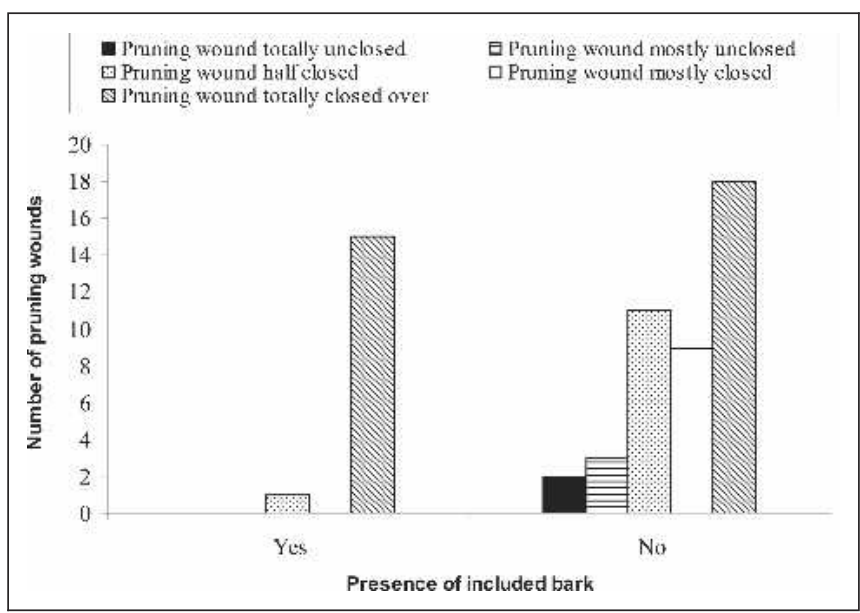

Figure 4. Closure of pruning wounds on branches with ( $n$ $=16)$ and without $(n=43)$ included bark. The Fisher exact test indicated that closure amount was dependent on the presence of included bark. 
small-diameter branches. Removing larger branches created a greater volume of dysfunctional wood. Therefore, urban trees should be managed to minimize the diameter of branches that will eventually require removal as they age.

The diameter of the cut branch may affect the development of discolored and decayed wood after branch removal, particularly in large branches that contain heartwood (Shigo 1986). The results from our study are most relevant for young tree (small branch) pruning; further study is necessary to test the relation between the aspect ratio and long-term trunk discoloration for branches in excess of $2.5 \mathrm{~cm}$ (1 in) in diameter.

Acknowledgments. The authors thank the TREE Fund and the GreatSouthernTreeConference.org for partial funding of this project.

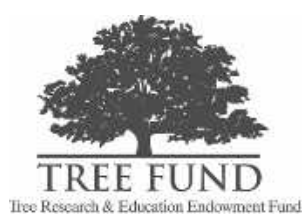

\section{LITERATURE CITED}

Biggs, A.R. 1989. Effect of pruning techniques on Leucostoma infection and callus formation over wounds in peach trees. Plant Disease 73:771-773.

Eisner, N., E.F. Gilman, J. Grabosky, and R.C. Beeson. 2002a. Branch morphology affects compartmentalization of pruning wounds. Journal of Arboriculture 28:99-105.

- 2002b. Branch junction characteristics affect hydraulic segmentation in red maple. Journal of Arboriculture 28:245-251.

Ewers, E.W., and M.H. Zimmermann. 1984. The hydraulic architecture of balsam fir. Physiologia Plantarum 60: 453-458.

Green, D.J., W.C. Shortle, and A.L. Shigo. 1981. Compartmentalization of discolored and decayed wood in red maple branch stubs. Forest Science 27:519-522.

Neely, D. 1988. Closure of branch pruning wounds with conventional and 'Shigo' cuts. Journal of Arboriculture 14: 261-264.

Pearce, R.B. 2000. Decay development and its restriction in trees. Journal of Arboriculture 26:1-10.

Pearce, R.B., and S. Woodward. 1986. Compartmentalization and reaction zone barriers at the margin of decayed sapwood in Acer saccharinum L. Physiological and Molecular Plant Pathology 29:197-216.

Shigo, A.L. 1985. How tree branches are attached to trunks. Canadian Journal of Botany 63:1391-1401.

-1986. A New Tree Biology. Shigo and Trees, Associates, Durham, NH. 595 pp.

Toole, E.R. 1961. Rot entrance through dead branches of southern hardwoods. Forest Science 7:219-226.

Von Aufsess, H. 1975. The formation of a protective zone at the base of branches of broad-leaved and coniferous trees and its effectiveness in preventing fungi from penetrating into the heartwood of living trees. Forstwiss Centralblatt 94:140-152.

. 1984. Some examples of wood discolourations related to mechanisms for potential protection of living trees against fungal attack. IAWA Bulletin 5:133-138.

Zimmermann, M.H. 1978. Hydraulic architecture of some diffuse porous trees. Canadian Journal of Botany 56: 2286-2295.

1983. Xylem structure and ascent of sap. In: Timmel, T.E. (Ed.). Springer Series in Wood Science. Springer Verlag, Berlin, Germany. 143 pp.

\section{Edward F. Gilman (corresponding author) \\ Professor \\ Environmental Horticulture Department \\ 1549 Fifield Hall \\ University of Florida \\ Gainesville, FL 32611, U.S. \\ egilman@mail.ifas.ufl.edu}

\section{Jason C. Grabosky \\ Assistant Professor \\ Department of Ecology, Evolution and Natural Resources \\ Rutgers University \\ New Brunswick, NJ 08901, U.S.}

Résume. Le diamètre de la branche par rapport à celui du tronc affecte l'étendu du bois décoloré et carié dans le tronc de semis d'érable rouge (Acer rubrum L.) après la coupe de la branche. Plus de décoloration résulte de la coupe de branches codominantes que de la coupe de branches plus petites que le tronc. La coupe de branches qui proviennent de bourgeons latéraux produit la même quantité de décoloration et de carie que la coupe de branches qui étaient autrefois des branches terminales. Ce résultat fournit une preuve indirecte que la coupe d'une petite branche codominante faite à l'aide de techniques d'élagage pour ralentir son taux de croissance peut produire une zone de protection au niveau du point de jonction. Il n'y a aucune relation entre la présence d'écorce incluse et la carie quatre ans après la réalisation des coupes.

Zusammenfassung. Der Astdurchmesser in Relation zum Stammdurchmesser beeinflußt nach der Astentfernung die Ausdehnung von verfärbtem und faulem Holz im Stamm von aus Sämlingen gezogenen Rotahornen. Weitere Verfärbungen resultierten eher von der Entfernung codominanter Stämmlinge als von der Entfernung kleinerer Äste. Die Entfernung von Baumteilen, die aus lateralen Knospen entsprangen führte zu ähnlichen Verfärbungen und Fäulnis als die Entfernung unterdrückter, früherer Leittriebe. Diese Ergebnisse liefern indirekt Beweis dafür, dass ein kleiner codominanter Stamm, der durch Schnitttechniken im Wachstum behindert wird, eine Schutzzone an der Verbindungsstelle zum Stamm schaffen 
kann. Es gab 4 Jahre nach dem Rückschnitt keine Verbindung zwischen dem Auftreten von Rinden-Inklusionen und Fäulnis.

Resumen. Se estudia la relación del diámetro de la rama con el del tronco y la manera en que es afectada la extensión de la madera decolorada y descompuesta en el tallo de brinzales de maple rojo (Acer rubrum L) después de la remoción de una rama. Resultó más decoloración de la remoción de tallos codominantes que de las ramas removidas, que eran pequeñas comparadas con el tronco. La remoción de los tallos originados de las yemas laterales resultó en la misma cantidad de decoloración y decaimiento que la de los tallos suprimidos que una vez fueron líderes. Este resultado proporciona evidencia indirecta de que un pequeño tallo codominante, suprimido por técnicas de poda designadas para reducir su tasa de crecimiento, puede resultar en la protección de la zona de unión de la rama. En cuatro años haciendo cortas de poda, no hubo relación entre la presencia de corteza incluida y el decaimiento. 